\title{
Ugarit Metinleri Çerçevesinde Baal Tapıcılığı ve İsrailoğulları'na Etkisi
}

Hakan OLGUN*

\author{
Baal Worship in the context of the Ugaritic Texts \\ and Its Effects on Israelites
}

Citation/@): Olgun, Hakan, (2014). Baal Worship in the context of the Ugaritic Texts and Its Effects on Israelites, Milel ve Nihal, 11 (2), 7-34.

Abstract: Israelites have deviated from the monotheistic faith in a significant period of their time. Baal, the pagan god of fertility deeply influenced the religious beliefs of the people of ancient Israel for a long time. In Ugarit, the most important information was obtained about the cult of Baal in archaeological inscriptions in the first quarter of the last century. This information sheds light on the understanding of the cult of Baal, which the Israelites had shared once in the Jewish sacred text. At the same time this information also explains the criticism of the Qur'an about the worshipping of Baal.

Key Words: Israelites, Ugarit, Baal, Elijah, paganism, Quran.

Atıf/@: Olgun, Hakan, (2014). Ugarit Metinleri Çerçevesinde Baal Tapıcılığı ve İsrailoğulları'na Etkisi, Milel ve Nihal, 11 (2), 7-34.

Öz: İsrailoğulları tarihlerinin önemli bir kısmında monoteist inançlarından sapmışlardır. Paganizmin bereket tanrısı Baal kültü uzunca bir süre İsrailoğulları'nın dini inançlarını derinden etkilemiştir. Geçen asrın ilk çeyreğinde Ugarit bölgesinde keşfedilen arkeolojik yazıtlarda Baal kültüne dair

* Doç. Dr., İstanbul Üniversitesi, İlahiyat Fakültesi, Dinler Tarihi Anabilim Dalı [holgun@istanbul.edu.tr] 
önemli bilgiler elde edilmiştir. Bu bilgiler Yahudi kutsal metnindeki İsrailoğulları'nın bir dönem sahip olduğu Baal kültünün anlaşılmasına ışık tutmaktadır. Aynı zamanda bu bilgiler Baal tapıcılığının Kur'an'da eleştirilme gerekçesini de aydınlatıcı mahiyettedir.

Anahtar Kelimeler: İsrailoğulları, Ugarit, Baal, İlyas, paganizm, Kur’an.

Peygamberler İsrail'i çağırdıkça, İsrail uzaklaştı onlardan. Kurban kestiler Baaller'e, buhur yaktılar oyma putlara.

Hoşea, 11:2

$* * *$

Şüphesiz İlyas da peygamberlerden idi. Hani kavmine şöyle demişti: “Allah'a karşı gelmekten sakınmaz mısınız? Yaratıcıların en güzelini, sizin ve geçmiş atalarınızın rabbi olan Allah'1 bırakarak Baal'e mi tapıyorsunuz?" Saffât, 124-126

\section{Giriş}

Temel dini ve tarihi doktrinlerini "Tanrı'nın seçilmiş kavmi" inancı üzerine inşa eden Yahudilik, dinler tasnifinde monoteist dinlerin ilki olarak sayılır. Monoteizm, tek tanrı inancı bağlamında farklı tanrısal unsurlara inanmayı, onlara tapınmayı ve taleplerde bulunmayı şiddetle reddeden bir anlama sahiptir. İsrailoğulları, rab Yahve'nin ilahi işareti ve peygamberlerin liderliğinde Mısır köleliğinden özgürleşip “vaadedilen topraklara” yerleşmiş bir kavim olarak bu Tanrı'ya iman konusunda güçlü telkinlerle muhatap olmuşlardır. On Emir hükümlerinin ilk maddeleri, İsrail halkına rablerinden başka tanrı tanımayacaklarına ve onun herhangi bir sûretini yapmayacaklarına dair uyarılar içermektedir. Ancak On Emir hükümlerinin ilgili telkinleri, İsrailoğulları'nın tarihi süreçlerinde pek çok kez ihlal edilmiştir. Bu durum, kutsal metnin işaret ettiği şekilde henüz Sina'da vahyin alınması sırasında buzağı tap1cılığı ile kendisini ortaya koymuştur. İsrailoğulları'nın rabbin yanı sıra farklı unsurlara ilahi nitelik atfedip pagan kült uygulamalarına bulaşmaları daha sonra da devam etmiştir. İsrailoğulları'nın Baal tapıcılığı bunun en göze çarpan örneklerindendir.

Kur'an, Hz. İlyas'ın dilinden "Allah'a karşı gelmekten sakınmaz mısınız? Yaratıcıların en güzelini, sizin ve geçmiş atalarınızın rabbi olan Allah'1 bırakarak Baal'e mi tapıyorsunuz?" sözleriyle İsrailoğulları'nın paganist sapkınlığının tarihsel gerçekliğini teyit etmektedir. Esasen İsrail halkının Baal kültünü benimsemeleri, Yahudi kutsal metinlerinde de işaret edilmekte ve onların bu tutumu çok sert bir dille eleştirilmektedir. Yahudi kutsal metni, İsrail halkının bir kısmının, özellikle iki krallıktan kuzeyde olan İsrail 
krallığı döneminde yoğun olarak Baal tapıcılığına meyillerini İlyas ve Hoşea peygamberler ile ıslah edilmeye çalışıldığını bildirmektedir. Dolayısıyla kendi tarihi süreci içinde İsrail halkının yüz yüze kaldığı en önemli tehditlerden birisi putperestlik olmuştur. Bu putperestlik kadim Orta Doğu'nun ilahlarına, özellikle de Kenan halkına ait tanrı ve tanrıçalara tapınmayla ilişkilidir.

İsrailoğulları'nın Baal tapıcılığını tanımlayıp peygamberlerin bu kült ile olan mücadelelerini ayrıntılı bir dille ifade eden Yahudi kutsal metni, asırlar boyunca söz konusu kült hakkındaki en tarihsel ve yegâne kaynak olmuştur. Bu kaynağa klasik Grek mitolojisi çerçevesinde "Baal" tanımına uygun diğer tanrısal unsurlarla kıyaslamalar da eklenmelidir. Ancak günümüzde artık Yahudi kutsal metninin yanı sıra bir başka kaynağa daha sahibiz: Ugarit yazıtları. $X X$. yüzyılın ilk yarısında keşfedilen Ugarit yazıtlarındaki verilerden Baal kültüne dair geniş bir bilgi yekûnuna sahip olunmuştur. Bu yazıtlar Baal kültü hakkında sunduğu bilgilerin yanı sıra Yahudi kutsal metnindeki Baal tapıcılığına ilişkin vurguları ve Yahve'nin Baal ile olan polemik dilini de açıklar mahiyettedir.

\section{Yahudi Kutsal Metin Anlatısında Baal Kültü}

Musa peygamberin yaşamının Moab dağında sona ermesiyle idareyi eline alan Yeşu bin Nun önderliğindeki İsrail halkı "vaadedilmiş topraklar"a girdiklerinde, şüphesiz bu bölge Kenan halkının ${ }^{1}$ ikamet ettiği kadim bir yerleşim bölgesini ifade etmektedir. Buna bağlı olarak bu topraklar Sina' dan beri vahyolunan monoteist inanç ile uyuşmayan pagan ve putperest bir kültürün mekânıdır. Yahudi kutsal metnindeki Baal anlatılarının dikkat çektiği en önemli husus, monoteist inanç mensuplarının yeni yerleşim yerlerinde güçlü bir pagan etkisinin altına girdiğidir. Bu durum, İsrail halkının monoteist inançlarını tehdit eden köklü bir pagan ve politeist geleneğe karşı tutumlarını ortaya çıkaracak bir vasat sunmuştur. Dolayısıyla İsrail halkının On Emir hükümleri çerçevesinde sadece ona ibadet edeceklerine dair Tanrı ile ahitleşmeleri (Çık. 20:1-6; Tes. 4:15-31) açısından vaadedilmiş toprakların paganist zemini önemli bir sınav ortamı olmuştur. Zira kutsal metin anlatılarından İsrail halkının yerli pagan inançlardan etkilendikleri anlaşılmaktadır. Nitekim peygamber Samuel, İsrail halkının meylettiği bu külte karşı şiddetle

1 Antik Kenan ülkesi sınırlarının günümüzde Suriye, Lübnan, Ürdün, İsrail ve Filistin topraklarını içerdiği ifade edilmektedir. Bkz. K. L. Noll, Canaan and Israel in Antiquity: An Introduction (New York: Sheffield Academic Press, 2001), s. 18. 
mücadele etme ihtiyacını duymuştur. İsrail'in kral Davut gibi kudretli yöneticileri tarafından da karşı konulan İsrail halkının Baal kültüne yönelik eğiliminin, bu dönemde en azından baskılandığ düşünülebilir. Bu baskı döneminde bile muhtemelen söz konusu kült gizli de olsa varlığını sürdürmüş ve monarşik dönemin İsrail kralı Ahab iktidarında resmen meşrulaştırılmış ve korunmuş bir inanç olarak İsrail halkı arasında yeniden gün yüzüne çıkmıştır. ${ }^{2}$ Dolayısıyla İsrailoğulları arasında Baal kültü, Yahudi kutsal metin kaynaklarına göre Hâkimler döneminden kuzeydeki İsrail krallı̆̆ döneminin sonuna kadar varlığını korumuştur.

Baal tapıcılığı, kadim Ugarit topraklarından güneye, Kenan bölgesini de içine alacak şekilde geniş bir coğrafyadaki bereket kültünün merkezinde yer almaktadır. Baal, antik dillerde "efendi", "sahip" ve "koca" anlamlarına gelmektedir. ${ }^{3}$ Genellikle yontularak insan şekli verilmiş olan Baal putuna, bağlıları tarafından dağların ve tepelerin zirvelerine sunaklar yapilır ve buralarda onun adına kurbanlar sunulurdu. Daha çok ağaçlık alanlarda ve korularda gerçekleştirilen Baal ayinleri için Baal putu yüksek sütunlar üzerine yerleştirilirdi. Kült merkezini oluşturan bu ağaçlık alanda ve koruluğun gölgesi altında tabiatın bereket dolu güzelliğini seyreden Baal tapıcıları kendi aile üyeleriyle birlikte cinsel içerikli ayinler düzenlerlerdi. ${ }^{4}$ Baal ritüellerinin mahiyeti çeşitli vesilelerle Yahudi kutsal metninin farklı kısımlarında ifade edilmiştir. Bu ritüeller, Baal sunağının çevresinde dans ederek dönmeyle başlamakta ve özel elbiseler giyinmiş olan Baal rahipleri kendilerini kılıç ya da mızraklarıyla yaralayarak bereket talebiyle kanlarını akıtmalarıyla devam ederdi. Kutsal fahişelik görevini üstlenmiş olan kadınlarla cinsel ilişkiler, ailenin, tarım alanlarının ve hayvan sürülerinin bereketini sağlamak adına icra edilen ritüelin bir parçasıyd $1 .{ }^{5}$ Genellikle cinsel ve ahlaki sınırsızlık içeren Baal tapıcılığında bu tür cinsel ayinlerin verimlilik ve bereketin yolunu açtığına, doğal enerji kaynağını canlandırdı-

Leon James Wood, A Survey of Israel's History (Grand Rapids: Zondervan, 1986), ss. 263-264.

3 Lamoine Devries, "Baal”, Mercer Dictionary of the Bible, ed., W. E. Mills, R. A. Bullard (Macon: Mercer University Press, 1997), s. 79.

4 Trent C. Butler, Holman Old Testament Commentary - Hosea, Joel, Amos, Obadiah, Jonah, Micah (Nashville: B\&H Publishing, 2005), s. 38.

5 Devries, "Baal”, s. 80. 
ğına inanılmıştır. Doğal ortamda sergilenen bu cinsel ritüellerin ardından Baal'e çeşitli hayvanlar kurban sunulurdu. Böylece Baal tapıcıları, kış günlerinden sonra yeniden canlanan tabiatın tarımsal olarak bolluk ve bereket getirmesi için verimlilik tanrısı Baal'e olan tapınma görevlerini yerine getirmiş olurlardı. ${ }^{6}$ Baal kültünün inanç olarak paganist, ritüel olarak da en azından ahlaki bir sapkınlık içeren bu tür tutum ve davranışlarının tek tanrıcı bir temele sahip İsrail inancının tamamen karşısında olduğu açıktır. Ancak İsrailoğulları'nın Kenan halkı ile temasları, onları bu tür Baal ritüelleri ile tanıştırmıştır.

İsrailoğulları'nın Baal inancına meyledip bunu bir kült merkezi haline getirilmeleri Yahudi kutsal metninde ayrıntılı bir şekilde öykülenmiştir. Kutsal metin anlatılarında "Baal" kelimesi 58 kez tekil, 19 kez de çoğul (baalim) olarak geçmektedir. Yine metinde Baal'in müstakil ve yegâne bir tanrısal unsur olarak görülmediği de dikkati çekmektedir. Nitekim burada Baal-hermon (Hak. 3:3), Baal-berit (Hak. 8:33), Baal-zebub (2 Kr. 1:2) gibi farklı coğrafi mekanlara ait Baal kültlerinden de söz edilmektedir. Kutsal metinde bu konunun ayrıntılı bir şekilde işlenmesi, Tanrı'nın İsrail halkı ile olan en çetin tartışmasının seçilmiş kavminin Baal kültüne eğilimi nedeniyledir. Bu eğilimi eleştiren pek çok metinde söz konusu tartışmanın Kenan Baalizmi ile İbrani Yahvizmi arasındaki çekişmeye dayandığı görülmektedir. Kutsal metinde rab Yahve'nin Baal kültüne meyleden İsrail halkına yönelik serzenişi daha çok 1. ve 2. Krallar, Hoşea ve başta 29. bab olmak üzere Mezmurlar' da yer almaktadır. Bu metinlerdeki anlatılara göre Yeşu bin Nun'un İsrail halkını Filistin'e getirmesiyle bu katı monoteist din, paganist etki tehlikesi ile karşılaşmıştı (Yşu 13:1-7; Hak. 1:22-35). İsrail halkının Kenanlılar ile bir arada yaşaması, karşılıklı evlilikler yapması, ticarette bulunması gibi kaçınılmaz nedenler sonucunda Kenan inancından etkilenmeler başlamıştır. (Hak. 2:11-15; Tes. 7:1-5).

Kutsal metin verilerine göre Baal kültünün İsrail halkı arasında krallığın mö. 930 yılında ikiye bölünmesinden sonra, özellikle kuzeydeki İsrail krallığı halkı arasında yaygınlaştığı anlaşılmaktadır. Bu külte yönelik eğilimlerin artmasından sorumlu tutulanlar kuzey İsrail tarihinin en önemli figürlerinden Kral Ahab ve eşi İzabel'dir.

6 Winkie Pratney, Devil Take the Youngest (Lindale: Minstry of Helps, 1985), ss. 57-58. 
Ahab'ın babası ve kuzey İsrail'in altıncı kralı sayılan Omri, krallığının çevresindeki diğer milletler ile dostluk arayışı içinde olmuş, bu amaçla Fenike ile bir anlaşma sağlamış ve oğlu Ahab'ı Sidon kralının kızı İzabel ile evlendirmiştir. Pagan inançlarına bağlı olarak yaşayan Sidon kralı, pagan tanrıçası Aşerot kültünün başrahibi sıfatını taşımaktadır. Bu dönemde Sidonlular, biri Aşerot diğeri Baal olan iki tanrısal unsura tapınmaktadır. Dolayısıyla İzabel hem ailevi hem de toplumsal çevre olarak böylesi pagan bir topluluk içinde yetişmiştir. Evlilik yoluyla İsrail toplumu içine giren İzabel, kocası Ahab'ı daha önce İsrail halkına yasaklanmış olan Baal ve Aşerot kültleriyle yeniden tanıştırmış (1 Kr. 16:30-31) ve böylece Ahab'ın İzabel ile olan evliliği İsrail halkı arasında Baal kültünün yaygınlaşmasını kolaylaştırmıştır. Ahab'ın ilk icraatı, İzabel'in isteği üzerine, hem Baal hem de Aşerot için krallığın başkenti Samarya'da birer tapınak inşa etmek olmuştur. ${ }^{7}$ Böylece IX. yüzyılda kral Ahab ve eşi İzabel döneminde (mö. 868-854) Baal kültü yaygın bir inanç uygulaması haline gelmeye başlamıştır. ${ }^{8}$ Bu nedenle olsa gerek, kutsal metin anlatılarına göre kral Ahab ve İzabel "Tanrı'nın gözünde daha önce hiç yapılmadığı kadar kötü işler yapmışlardır" (1 Kr. 16:30). Bu suçlamanın temel sebebi, elbette İzabel'in kendi yerli dinini, Baal kültünü İsrail'e taşıması ve Ahab'ın bu işe imkân vermesidir.

Monoteist bir toplum içinde pagan ve politeist inançların yaygınlaşmasına sebep olan İzabel hakkında kutsal metinde çokça söz edilmekte ve hep kötü sıfatlarla yerilmektedir. Bu metinde İzabel, Baal tapıcısı (1 Kr. 16:31); eli kanlı katil (1 Kr. 21:1-16; 2 Kr. 9:7); soyguncu (1 Kr. 21:1-6); aile mirası içindeki kutsal kurallara saygısızlık yapan (1 Kr. 21:1-6); korkutan, göz dağ1 veren ve hileler yapan (1 Kr. 18:1-2); Tanrı'nın peygamberlerini ortadan kaldırarak yerlerine Baal rahiplerini getiren (1 Kr. 18:4, 13); resmi idarenin arkasına gizlenerek icrada bulunan ve bu çerçevede Ahab adına mektuplar yazarak gönderen (1 Kr. 21:8); kendisine karşı direnen ya da yeterince saygı göstermeyen insanları korku ve endişeye sevk eden (1 Kr. 19:3-4); kötülük ve kışkırtıcılık yapan (1 Kr. 21:25); fahişe (2 Kr. 9:30); Baal tapıcılığı uğruna büyücülük yapan ve Tanrı ile onun halkına karşı

7 Steve Sampson, Confronting Jezebel: Discerning and Defeating the Spirit of Control (Bloomington, Chosen Books, 2012), s. 6.

8 Bkz. Brad E. Kelle, Hosea 2: Metaphor And Rhetoric in Historical Perspective (Atlanta: Society of Biblical Literature, 2005), s. 140. 
son derece isyankar olan (1 Sam 15); ve erkekleri hadım eden (2 Kr. 9:32) gibi yönleriyle tanımlanmaktadır. Söz konusu kutsal metin ifadelerinden Baal kültünün İsrail krallığı içinde yaygınlaşması için İzabel idari otoritenin de verdiği gücü kullanarak oldukça etkin faaliyetlerde bulunmuştur. Baal kültünün çok sayıdaki rahiplerini desteklemiş ve onları Yahve'nin peygamberlerini ortadan kaldırmaları için kışkırtmıştır.

Kutsal metin anlatısı çerçevesinde (1 Kr. 18) Baal kültüne karşı en çetin mücadele İlyas peygamber tarafından verilmiştir. Bu anlatıya göre Yahve tarafından Baal inancına karşı mücadele etmekle görevlendirilen peygamber İlyas, kral Ahab'ın karşısına çıarak onu “Sen Rabbin emirlerini terk ettin ve Baaller'in takipçisi oldun" diyerek suçlamıştır. Ardından peygamber İlyas halka dönerek “Daha ne zamana kadar böyle iki taraf arasında gidip geleceksiniz? Eğer rab Tanrı'ysa, onu izleyin; yok eğer Baal Tanrı'ysa, onun ardınca gidin" der. Krala ve halka yönelik bu suçlamalardan sonra peygamber İlyas insanların kurbanların kabul eden ya da dualarını işiten merciinin Baal değil tanrı Yahve olduğunu ispat etmek amacıyla ilginç bir girişimde bulunur. Peygamber İlyas, Baal'in ve Aşerot'un rahipleriyle birlikte İsrail halkının Baal kültüyle büyük mücadelesinin mekânı olan Karmel dağında toplanmalarını ister. Bu dağda peygamber İlyas Yahve'ye, Baal rahipleri ise Baal'e kurban sunacak ve gerçek tanrıyı keşfedeceklerdir. Her ikisi de ateşi kontrol eden tanrı olarak inanılan Baal ve Yahve'den hangisinin bu kurbanlardan kendilerine sunulanı ateşle karşılık verip kabul edeceği sınanmıştır. Baal'in rahipleri kendi sundukları kurbanlarının kabulü için sabahtan akşama kadar dua etmelerine ve yüksek manevi coşkunluk içerisindeki yakarışlarına rağmen Baal'den herhangi bir kabul işareti alamazlar. İlyas peygamber ise Yahve'ye dua ettikten sonra kurban sunumunda bulunur ve Yahve hemen ateşle karşılık vererek onun kurbanını yakıp kül eder. Bu durum, Baal'in kendisine sunulan kurbana cevapsız kalırken İlyas peygamberin kurbanının Yahve tarafından kabulü anlamına gelir. Bunun üzerine halk "gerçek tanrı Yahve'dir" diyerek bâtıla bulaştıklarını itiraf ederler. Ancak İlyas peygamber, sahte peygamberlerin öldürülmesini içeren kutsal yasa emri gereği (Tes. 13:5) halkın Baal rahiplerini öldürmesini ister. Anlatının sonunda Yahve kuraklıktan mahvolmuş Baal'in topraklarına bolca yağmur indirir. Artık İsraillilerin yağmur ve verimlilik için boş yere Baal'e başvurmalarına ihtiyaç kalmamıştır. 
Karmel dağında yaşanan bu dramatik tecrübe, Baal kültünün İsrail halkı üzerindeki etkisini tamamen ortadan kaldırmamıştır. Tanrı Yahve'nin sunulan kurbanı kabulüyle Baal kültü üzerindeki baskın çıkışına rağmen İsrail halkı arasında bu külte yönelik eğilimin devam ettiği görülmektedir. Bu konuda kutsal metnin Hoşea bölümünde oldukça ayrıntılı bir anlatı söz konusudur. Bu anlatıya göre Yahve'nin peygamber Hoşea'nın iffetsiz bir kadınla evlenmesi istenmiş ve bu evlilikten doğan çocuklar üzerinden İsrail halkının Baal paganizmine meyletmeleri eleştirilmiştir (Hoş. 1:2-9). Kutsal metin anlatısında İsrail halkı Yahve tarafından "kocasını terk eden ve başkasına kaçan kadın" a benzetilmiş ve İsrail, kendisini terk edip başka tanrıların, özellikle de Baal'in peşine düşen Yahve'nin karısı olarak tasvir edilmiştir. Hoşea'nın evlendiği kadın olan Gomer'den doğan ilk çocuğuna Yahve tarafından "Yizreel" adı konulmuştur. İsrail krallığı halkından Yizreel vadisinde öcün alınacağı bildirilmiştir. Gomer' in dünyaya getirdiği çocuklardan ikincisine "merhamete ermeyecek" anlamina gelen "Lo-Ruhama" konulmuştur. Çünkü Yahve artık İsrail soyuna acımayacaktır. Zira Yahve hemen ardından, putperestliğe bulaşmış olan kuzeydeki İsrail krallığı halkının aksine güneydeki Yahuda soyuna acıyacağını bildirmiştir. Gomer'den doğan son çocuk ise "benim halkım değil" anlamına gelen "Lo-Ammi" adını taşır. Ardından Yahve "çünkü siz benim halkım değilsiniz, ben de sizin tanrınız değilim" sözünü ekler. Metnin devamındaki ifadelerden de anlaşılacağı üzere, Gomer'in son çocuğu da iffetsiz bir hatanın ürünüdür ve bu durum kadının kocasına yönelik büyük bir sadakatsizliği ifade etmektedir. ${ }^{9}$

Anlatıda dile getirilen Hoşea'nın iffetsiz bir kadınla evliliği ve çocuklara verdiği isimler, Yahve'nin İsrail halkına yönelik tenkidini gösterir. Esasen bu alegorik anlatıda Hoşea "tanrı Yahve"yi, karısı Gomer ise "Yahve'nin seçtiği İsrail halkı"nı sembolize etmektedir. Hoşea, karısının iffetsizliğinden dolayı uzun süredir ıstırap çeken koca formunda Yahve' dir; kocasına karşı sadakatsiz eş olan Gomer ise başka tanrılara meyleden İsrail halkıdır. Tanrı'nın seçilmiş halkı, kendisine olan başlangıçtaki sevgisini kaybetmiş ve başka tanrılara yönelmişlerdi. ${ }^{10}$ Nihayet Yahve halkı ile arasındaki anlaşmayı sona

Erin Wolff, A Heart After God (Lake Mary: Creation House, 2013), s. 106.

10 V. H. Matthews, J. C. Moyer, The Old Testament: Text and Context (Grand Rapid: Baker Academic, 2012), s. 137. 
erdirmeye karar vererek başıboş kalıp kendisinden uzaklaşan halkına yargılamanın yaklaştığını bildirir.

Yahve'nin İsrail krallığı halkına yönelik bu eleştirisinden sonra şiddetli bir öfke hali içerisinde olduğu görülür. Yahve'nin İsrail halkını hedefleyen gazaplı serzenişi, Hoşea metninin ikinci babında (Hoş. 2: 1-23) çok keskin bir dille ifade edilmektedir. Hoşea'nın dilinden halkına seslenen Yahve, Gomer'in (İsrail halkı) iffetsiz bir zinakâr olduğunu, bu nedenle onu adeta bir çöle çevirip susuzluktan öldüreceğini; zina ürünü olan çocuklarına da acımayacağını bildirir. Karısı Gomer'in, ihtiyaç duyduğu ekmeği, suyu, yapağıyı, keteni, zeytinyağını ve şarabı verdiğini düşündüğü kişilerin ardından giderek iffetsizlik ve sadakatsizlik yapmasını eleştiren Yahve, hâlbuki bu nimetleri ona Hoşea formu üzerinden kendisinin verdiğini ifade eder. Hatta onun Baal'e takdim ettiği altın ve gümüşleri ona bol bol bağışlayanın kendisi olduğundan habersizliğine işaret eder. Gomer'in bu suçu nedeniyle iffetsizliğinin karşılığı olarak kendisine verilen asmaları ve incir ağaçlarını viraneye çevireceğini söyler.

Yahudi kutsal metin anlatılarından İsrailoğulları'nın Baal kültüne meyledip putperestleşmesinin iki açıdan resmedildiği görülmektedir. Birincisi, İsrailoğulları çevre kültürün pagan inançlarından etkilenerek Baal kültü çerçevesinde putperestliğe sapmış olmalarıdır. Rab, İsrailoğulları'nı bu batıl tutumlarından vaz geçirmek için özellikle İlyas peygamber aracılığıyla uyarılarda bulunmuştur. Söz konusu anlatının ikinci boyutu, İsrail halkının Baal kültüne meyletmesinin gerekçesini ifade etmektedir. Tarım ve ziraat işleriyle uğraşan İsrailoğulları'nın dünyevi nimetler için bu paganist inanca yönelmiş olduklarına işaret edilmektedir. Hâlbuki onlara ihtiyaç duydukları nimetleri bahşeden Baal değil rab Yahve'dir. Yahve, İsrailoğulları'nın nankörlügünü oldukça metaforik bir anlatımla, kocasını terk eden kadının vefasızlık ve sadakatsizliği hatta bir başka kocaya kaçması yönüyle de iffetsizliği ile tanımlamaktadır.

\section{Ugarit Metinleri ve Baal Mitolojisi}

Yahudi kutsal metninde İlyas peygamber örneği ya da Hoşea'nın eşi metaforu üzerinden tanımlanan İsrailoğulları'nın Baal kültüne eğilimlerinin tek bir bakış açısıyla anlatıldığı görülmektedir. Yahve'nin Baal karşısında bereketin kaynağı olarak neden kendini gösterdiği ya da Hoşea'nın günahkâr eşi örneği üzerinden İsrail halkını neden kocasını terk eden kadına benzettiği, uzun süre bir yorum konusu 
olarak kalmıştır. Çünkü Baal kültüne ait tarihsel bilgilerin uzun süre kaynağını Yahudi kutsal metni oluşturmuştur. Ancak 1929 yılında Ugarit'te keşfedilen önemli arkeolojik veriler, Baal kültü hakkında meseleye farklı açıdan bakan bir bilgi kaynağı olarak eklenmiştir. Bilim dünyasına Ugarit yazıtları olarak geçen bu kaynak temel olarak iki hususa dair açık bilgiler ihtiva etmektedir. Birincisi, bu yazıtların keşfiyle Baal mitolojik anlatılarının önemli bir kısmına ulaşılmış ve kadim Kenan dininin geleneksel litürjik uygulamaları ve teolojik-mitolojik söylemlerini yansıtan pek çok bilgi elde edilmiştir. Böylece Baal kültüne dair kutsal metin dışında yeni tarihsel bilgilere sahip olunmuştur. İkincisi, keşfedilen Baal mitolojik metinleriyle kutsal metinde Yahve'nin dile getirdiği pek çok ifade, metaforik anlatım ve İsrail halkına yönelik Baal kültü çerçevesinde tehdit ve telkinlerin arka planına dair önemli veriler ortaya çıkmıştır. Dolayısıyla kutsal metnin ilgili cümle ve pasajlarının, keşfedilen söz konusu mitolojik veriler ışığında tahlil edilmesine imkân sağlanmıştır. Kenan diyarının dini literatürüne ait pek çok otantik bilgiyi içeren Ugarit yazıtları filologların, dinler tarihçilerinin ve Kitab-1 Mukaddes araştırmacılarının ilgisini çekmiştir.

Arkeolojik kaynağın bulunduğu Ugarit bölgesi, esasen kadim Ugarit krallığının coğrafyasıdır. Ugarit, Suriye sahillerindeki kuzey Lazkiye'ye 12 km. mesafedeki günümüzde Ras Şamra olarak bilinen bölgede yer alan ve aynı zamanda krallığın da başkenti olan kadim bir yerleşim biriminin adıdır. ${ }^{11}$ Ugarit'te keşfedilen yazıtların mö. 1400-1200 y1llarına ait olduğu ifade edilmektedir. Bu dönemde Ugarit krallığ1 Babil, Asur, Hitit, Harran, Girit, Kıbrıs, Arap ve Mısır bölgelerinden gelen farklı milletlerin önemli bir kesişme merkezini ifade etmektedir. ${ }^{12}$ Ugarit yazıtları, İbranice' ye çok yakın bir dil olan ve kuzey-batı semitik dili olan Ugaritçe olarak yazılmıştır. Mitolojik anlatıları içeren bu metinlerden, özellikle Kenan dinini, ibadet sistemini ve daha çok Baal kültünü anlamaya imkân veren önemli veriler elde edilmiştir. Baal mitolojik metinleri altı tablet üzerine iki yönlü olarak ve genellikle altı sütuna işlenmiş yazıları içermektedir. ${ }^{13}$

11 An Anthology of Religious Texts from Ugarit, ed. J. C. de Moor (Leiden: Brill, 1987), s. vii.

12 An Anthology of Religious Texts from Ugarit, s. viii.

13 John Gibson, "The Mythological Text", Handbook of Ugaritic Studies, ed. W. G. E. Watson, N. Wyatt (Leiden: Brill, 2003), s. 193. 
Arkeolojik metinlerde tespit edilen Ugarit mitolojisi, Kenan halkının inancıyla büyük benzerlik içinde bir tanrılar panteonuna sahiptir. Ugarit yazıtlarında tanrılar panteonu temel olarak üç tanrısal figürü içermektedir: El, Dagan ve Baal. Ugarit mitolojisinde tanrılar panteonunun zirvesinde El yer almaktadır. Mitolojik metinde El'e atfedilen sifatlar onun birincil konumunu ifade etmektedir: "Yarat1cımız El gerçekten ebedidir. Asla yaşlanmayan o bizi vücuda getirdi" (KTU. 10.3.6). ${ }^{14}$ El, Ugarit panteonunda yaratıcı tanrıdır; aynı zamanda diğer tanrısal figürlerin de babasıdır. Mitolojide Baal bir başka tanrısal unsur olan Dagan'ın oğlu olarak anılır. Buna rağmen El, Baal'in babası ve atası olarak ifade edilir: "El onun (Baal'in) babasıdır. Onu El yaratmıştır" (KTU 3.5.43). El, aynı zamanda ezeli ve ebedi tanrı olarak tanımlanır: "Ey El, senin hükmün hikmettir. Senin bilgeliğin ebedidir" (KTU. 4.4.41). ${ }^{15} \mathrm{El}$, kozmosun idarecisi ve "tanrıların babası" olarak anılmasına rağmen çocuklarının sıradan işleriyle ilgilenen pasif bir ata konumda resmedilir.

Ugarit mitolojisinde El ve Baal'in yanı sıra Athira, Anat, Mot ve Yamm gibi farklı tanrısal unsurlardan da söz edilmektedir. El'in eşi ise Kenan tanrıçası Aşerot ile ilişkilendirilen Athira'dır. Diğer tanrısal figürler daha çok tabiat fenomenleriyle ilişkilidir. Baal, fırtına tanrısıdır ve Dagan'ın enerjik oğludur. Ancak Baal, tanrıların lideri olduğu için El'e "baba" diyerek seslenmektedir. Ayrıca Yamm deniz, Şapş güneş, Yarih ay, Mot ölüm, Anat avcılık ve savaş tanrılarıdır. Bunların yanı sıra mitolojik bir çalgı aleti olan lir ile ve salgın hastalıklarla ilişkilendiren daha pek çok tanrısal unsurlardan söz edilmektedir (KTU, 1.47, 1.118, 1.23). ${ }^{16}$

Ugarit mitolojisine göre tanrılar panteonun zirvesinde tanrı El yer almakla birlikte Baal, halkın gündelik yaşamına ait pek çok hususta etkili olması nedeniyle öne çıkmıştır. Dolayısıyla mitolojik metinde diğer tanrısal unsurlara nazaran Baal'in fonksiyon ve serüvenlerinden daha fazla söz edilmektedir. Arkeolojik bulgularda yer alan metinlere göre Baal, Kenan tanrılar panteonunda çok bilinen ve oldukça etkin bir tanrısal figürü ifade etmektedir. Bu metinlerde Baal "bulutların binicisi” (KTU 1.3 II 40) adıyla fırtına tanrısı

14 Frank Moore Cross, Canaanite Myth and Hebrew Epic: Essays in the History of the Religion of Israel (Cambridge: Harvard University Press, 1997), s. 15.

15 Cross, Canaanite Myth and Hebrew Epic, ss. 15-16.

16 W. M. Schniedewind, J. H. Hunt, A Primer on Ugaritic Language, Culture and Literature (Cambridge: Cambridge University Press, 2007), ss. 17-18. 
ve yağmuru yağdıran bir bereket tanrısı olarak tanımlanmıştır. Ayrıca Baal, düzenli tarımsal döngüleri sağlamak için ölüm-verimsizlik güçleriyle savaşan ve zirai bereket için yeni tarım dönemlerini başlatan güçlü ve savaş̧̧ı bir tanrı olarak sunulmaktadır. Dolayısıyla ziraat toplumu olan bölge halkı için Baal adeta yaşam verici bir tanrı olarak düşünülmüştür. ${ }^{17}$

Ugarit yazıtlarında Baal'in rolünü ve başarılarını içeren iki öykü anlatılmaktadır. Bunlardan birisi Baal'in denizi sembolize eden Yamm diğeri ise ölümü sembolize eden Mot ile olan mücadelesidir (KTU 1.2-6). ${ }^{18}$ Baal'in bir ejderha görünümündeki Yamm ile savaşı ve sonuçta onu yenmesi, kaosun kaynağı olan bu devi ortadan kaldırması, onun tanrısal rolünü ifade etmektedir. Baal tarafından yenilgiye uğratılan Yamm kendi alanı olan denizlere hapsolmuştur. Baal'in, ölüm tanrısı Mot ile yaptığı mücadele ise ilginç bir şekilde onun verimlilik tanrılığı yönünü ortaya çıkarmaktadır. Esasen Baal'in Mot ile yaptığı mücadele döngüsel bir zaman anlayışına ifade etmektedir. Bu ikinci öyküde Baal, Mot tarafından yenilgiye uğratılır ve ölüm âlemi olan yeraltına iner. Bir süre sonra tekrar dirilerek ortaya çıar ve Mot'a karşı zafer kazanır. Baal'in ölüp yeraltına inmesi ve daha sonra dirilip Mot'a galip gelmesi tabiatın mevsimsel döngüsü olarak anlaşılmıştır. Baal'in yokluğunda yağmurlar kesilir ve tarım toplumu için verimsiz bir dönem başlar. Baal'in yeniden dirilip ortaya çıkması baharın gelişini müjdeler ve başlayan yağmurlar ile verimlilik artar.

Bu arkeolojik buluntuda resmedilen Baal ile Kenan halkının tarım ve bereket tanrısı olan Baal arasında birbiriyle örtüşen özellikler söz konusudur. Bu nedenle Ugarit yazıtlarında, İsrailoğulları'nın Baal tapıcılı̆̆ının gerekçelerini anlamaya imkân veren iki husus öne çıkmaktadır.

Mitolojik Ugarit anlatısında dikkat çeken ilk husus, tanrılar panteonunun tepesindeki yüce tanrisal unsur El'dir. Ancak El, icraat sahibi bir tanrısal unsur olmaktan ziyade yaşamın gündelik boyutundan uzaklara çekilmiş aşkın bir tanrıyı ifade etmektedir. Din araştırmaları literatüründe $\mathrm{El}$, yeryüzünden ve insanlardan tamamen uzaklaşarak evrenin ötesinde yer alan ve bu haliyle kullarının gündelik işlerine müdahil olmayan hatta bu işlerden bihaber olan

17 Walter Brueggemann, Reverberations of Faith: A Theological Handbook of Old Testament Themes (Louisville: John Knox Press, 2002), s. 15.

18 Nick Wyatt, Religious Texts from Ugarit, ss. 36-38 
aşkın tanrı/deus otious olarak ifade edilebilir. Bu tür bir aşkın tanrıya insanların gündelik ihtiyaçları için dua ve seslenişte bulunmalarının bir anlamı yoktur. Çünkü ötelerin ötesine çekilmiş olan bu aşkın tanrı, kullarının seslenişlerini duymayacak kadar yeryüzünden uzaktır. Böylece, aşkın tanrı inancı etkin ve egemen olmayan bir unsuru ifade ettiği için gündelik hayatta önemli bir ilahi egemenlik boşluğunun doğmasına yol açmıştır. Anlatıda dikkat çeken ikinci husus ise insanların gündelik yaşamındaki bu boşluğun daha fonksiyonel bir tanrısal unsur ile doldurulmasıdır. Bu unsur Baal olarak resmedilmiştir. Baal, yeryüzüne bolluk ve bereketi getiren, insanların gündelik ihtiyaçlarını karşılayan, onlara tarım ve ziraat ürünlerini sağlayan bir ilahi güç olarak tanımlanmıştır. Aynı zamanda Baal, insanları korku ve endişeye sevk edip onları bereketsizlik ve ölümle tehdit eden diğer tanrısal unsurlara karşı da varlığını ortaya koyarak mücadele eden bir kahramandır.

\section{Baal ve Yahve}

Ugarit yazıtlarını Yahudi kutsal metnindeki ilgili anlatılar ile birkaç açıdan ilişkilendirmek mümkündür. Bunlardan birisi, söz konusu mitolojiyi içeren metnin dili Ugaritçe'nin İbranice ile pek çok ortak kelime ve cümle yapısına sahip olduğudur. Özellikle kurban ritüeli çerçevesinde takdime sunumu ve bu takdimelerin yakılmasını içeren kurban ritüelinde kutsal metnin teknik ifadelerini içeren kavramlar ile yazıtların dili arasında yakın bir benzerlik söz konusudur. ${ }^{19}$ Ancak en önemli benzerlik "Baal” kelimesi çerçevesinde ortaya çıkmaktadır. Zira tekil ve çoğul şekliyle "baal" kutsal metinde pek çok kez zikredilmiştir. Ugarit metinlerinin keşfinden önce "baaller" müstakil olarak Kenan tanrısal varlıkları ile ilişkilendirilmiştir. Buna göre her Baal kendi ayrı yerel kimliğine sahiptir. Ugarit yazıtları ise Baal'in, büyük bir kozmik tanrı olan Hadad'ın insani tarz içinde tanımlanması olduğunu açığa çıkarmıştır. Böylece bölgesel baaller bu özel tanrının yerel görünümü olarak anlaşılmıştır. ${ }^{20}$

Esasen Ugarit yazıtlarında Kenan tanrilar panteonunun tepesinde yer alan El'in, kendisine atfedilen özellikler bağlamında Yahve ile benzeştirilmesi mümkündür. El, şefkat ve hikmet sahibi,

19 E. H. Merrill, M. F. Rooker, M. A. Grisanti, The World and the Word: An Introduction to the Old Testament (Nashville: B\&H Publishing, 2003), s. 48.

20 John Day, Yahweh and the Gods and Goddesses of Canaan (Sheffield: Sheffield Academic Press, 2002), s. 68. 
ilahi yargıç olması, yaratıcı ve baba olduğu kadar ilahi konseyin başı olması, krallığı, çadırı ve tahtı ile Yahve'ye ait pek çok temel unsura sahiptir. Ancak El, bu yönleriyle Yahve'nin karakterinin sadece bir parçasını yansıtmaktadır. Fakat temel özellikleri bağlamında Baal, prensipte Yahve'ye daha çok benzeştirilmektedir. Baal, bulutların üzerindeki fırtına tanrısı olarak doğal dünyadaki güçlü etkisiyle betimlenmektedir. Baal, tıpkı Yahve gibi maiyetiyle birlikte savaşmak üzere düşmanlarının üzerine yürümekte, savaştan döndüğünde kutsal dağındaki mabedine çekilmektedir. ${ }^{21}$ Baal'e atfedilen özelliklerin içinde yer aldığı teofanisi dikkate alındığında onun daha çok Yahve'nin teofanisi içinde yansıdığı oldukça açıktır.

Mitolojik veriler ve kutsal metin anlatıları arasındaki ilişkinin en önemli yönü, Yahudi kutsal metnindeki bazı öykülerin ve Yahve'ye ilişkin sıfatlandırmaların çözümünde söz konusu mitolojinin açıklayıcı etkisidir. Örneğin İlyas peygamberin Baal yanlılarına karşı sürekli dile getirdiği "yağmurun ve bereketin kaynağının Yahve olduğu" ve "Yahve'nin yaşayan tanrı olduğu" söyleminin gerekçesi Ugarit yazıtlarında keşfedilebilmektedir. Söz konusu yazıtların 1şık tuttuğu diğer bir önemli kutsal metin vurgusu ise Yahve'nin yağmurun, şimşeğin ve fırtınanın egemeni olduğudur. Baal kültünün İsrail kralı Ahab ve eşi İzebel ile birlikte kuzey krallığına egemen olmasından ve Baal tapıcılığının teşvik etmesinden sonra İlyas peygamber şöyle der: "Gilat'ın Tişbe Kenti'nden olan İyas, Ahab'a şöyle dedi: "Hizmet ettiğim İsrail'in Tanrısı yaşayan rabbin adıyla derim ki, ben söylemedikçe önümüzdeki yıllarda ne yağmur yağacak, ne de çiy düşecek" (1 Kr. 17:1). İlyas peygamber bu söylemi dile getirmesi için tanrının yaşadığından söz etmesi, Ugarit anlatısı çerçevesinde daha gerçekçi bir anlam bulmaktadır. Yağmurun yağmaması her toplum için sıkıntılara sebep olacaktır fakat İlyas peygamberin bu sözü Ahab ve İzebel'e karşı dile getirmesi, doğrudan İsrail halkının Baal tapıcılığına yönelik bir reddiyedir. Çünkü Ugarit mitolojik metinlerinin işaret ettiğine göre Baal, fırtınaları, şimşeği ve yağmuru kontrol eden tanrı olarak düşünülmüş ve bu nedenle verimlilik ve bereket tanrısı sayılmıştır.

Ugarit yazıtlarında Baal'in bereket kaynağı olarak tabiatı yenileyici etkisine güçlü bir şekilde işaret edilmektedir. Tabiatın yenilenmesi ise yine mitolojik bir kavganın sonucuna bağlıdır. Baal'in

21 Patric D. Miller, The Religion of Ancient Israel (Luisville: Westminister John Knox Press, 2000), s. 25. 
en önemli düşmanlarından birisi “ölüm”e ilişkin tanrısal unsur olan Mot'tur. Yapılan kavgada Mot nihayet Baal'i öldürür ve Baal yeraltındaki ölüm âlemine gönderilir. Bu sırada mevsim, yağmursuz, k1sır ve verimsizlik aylarıdır. Fakat Baal bir süre sonra Mot'u yenerek yeniden hayata döner ve baharı müjdelediği yeryüzünün verimliliğini onarır. Ugarit yazıtlarında El, Baal'in Mot'u yenip ölüm üzerine egemen oluşuna dair dile getirdiği kehanette Baal'in verimliliğini şöyle ifade ediyor: "İşte, yüce Baal yaşıyor / İşte hükümdar / yeryüzü varlıklarının efendisi / Gökler yağ indiriyor / Vadilerden şarap akıyor." (KTU 6.3.3-6)22 Ugarit anlatısında bu iki tanrısal unsur arasindaki mücadele hep devam eder. Kurak mevsim Mot'un, yağışlı mevsim ise Baal'in egemen olduğuna işaret eder. İlyas peygamber ise bu inancın aksine, Tanrı Yahve'nin mevsimsel olarak değil her daim yaşayan olduğunu ifade ederek yağmurun yağdığında bunun Baal'in değil Tanrı'nın isteğiyle olduğunu belirtir. Bütün peygamberler aracılığıyla Tanrı Yahve, Baal'in otoritesine doğrudan meydan okumaktadir. ${ }^{23}$

Kutsal metnin Hoşea bölümünde anlatılan kanlı matem ritüeli, Baal kültünün bereket ayinini aktaran Ugarit yazıtları çerçevesinde önemli bir anlam kazanmaktadır. Hoşea bölümünde (7:14) İsrailoğulları'nın ilginç bir yakarış ritüelinden söz edilmektedir. Ritüel, İsrailoğulları'nın tahıl ve şarap için kendilerini yaralamalarını ifade etmektedir. ${ }^{24}$ Benzer bir anlatı 1 Krallar bölümünde de (18:28) zikredilmektedir. Peygamber İlyas'ın önerisi üzerine onunla birlikte kendi tanrılarına kurban sunan Baal peygamberleri, Baal'in ateş gönderip kendi sunularını kabul etmesi için “yüksek sesle bağırmakta ve adetleri uyarınca, kılıç ve mızraklarla kanlarını akıtıncaya dek kendilerini yaralamaktadırlar." Bu ritüel Baal kültü içinde aşırı keder ve üzüntünün varlığına işaret etmektedir. Yine bu mitolojik metinlerde, Baal'in öldüğü haberini alan El ve Anat ilginç bir matem ve ağıt ritüelini uygulamaktadırlar. El ve Anat bu ölüm haberi üze-

Cross, Canaanite Myth and Hebrew Epic, s. 118.

23 Merrill, Rooker, Grisanti, The World and the Word: An Introduction to the Old Testament, s. 15.

24 "Yürekten yakarmıorlar, Uluyorlar yataklarının üzerinde. Tahıl ve yeni şarap için kendilerini yaralıyor. Bana sırt çeviriyorlar." 
rine taşlarla derilerini yırtıp yaralamakta ve bıçaklarla yanak ve çenelerini çizerek kanatmaktadırlar. ${ }^{25}$ Baal kültünde aynı zamanda ölüm ağıtı olarak da gerçekleştirilen bu uygulamada vücudun çeşitli yerlerinin yaralanarak ya da kesikler atılarak vücudun kanatılmasını ifade etmektedir. Yahudi kutsal metin hukukunda yasaklanan bu davranış bir ritüel modunda ve aynı zamanda "Baal! Baal!” diye bağırılarak Baal rahipleri tarafından gerçekleştirilmiştir. Muhtemelen bu tutum ile Baal'in kendilerini duyup harekete geçmesini ve ona sundukları kurbanı kabul etmesini arzulamaktaydılar. ${ }^{26}$ Dolayısıyla Ugarit yazıtları Baal kültüne ait ritüelleri ortaya koyarak kutsal metnin bu konudaki anlatılarına 1şık tutan bir kaynak olarak değerlendirilmektedir. ${ }^{27}$

Yahudi kutsal metninin Hoşea bölümünde İsrail halkının Yahve tarafından "kocasını terk eden ve başkasına kaçan kadın"a benzetilmesi çerçevesinde İsrail halkı, kendisini terk edip başka tanrıların, özellikle de Baal'in peşine düşen Yahve'nin karısı olarak tasvir edilmiştir. Burada evlilik teması, doğrudan Baal kültü terminolojisinden geldiği için oldukça uygundur. Esasen ziraat kültüründe yeryüzünün yağmur ve tohumla gebe kalıp verimli hale geldiği tasavvuru vardır. Bu tasavvur kolayca tanrıların cinselliğine vurgu yapan mitlerle ilişkilendirilir. Hoşea metni, İsrail'in Baal ile bir "evlilik" halinde olduğunu, daha doğrusu kocasını terk edip Baal ile yeni bir evlilik kurduğunu açıklamaktadır. Daha da kötüsü, bu durum açıkçası bir zina durumunu ifade etmektedir; çünkü İsrail'in Yahve'den aile bağının sona erdirilmesi anlamında hukuken

25 "Yeryüzünün hükümdarı ve efendisi mahvolmuştu. / Bunun üzerine şefkat ve merhamet tanrısı tahtından indi. / Önce iskemlesine oturdu, sonra iskemleden inerek yere oturdu. / Sonra matem küllerini, tozu toprağı başından, tacından aşağı döktü. / Kendisini bir parça bez ile örttü ve bir taş ile derisini yaraladı. / Bir ustura ile kesti. / Kolunun kemiğini tırmıkladı. / Göğsünü sabanla sürülmüş tarla gibi paraladı. / Sırtını bir vadi gibi yardı. / Bu sırada sesini yükselterek şöyle bağırıyordu: Baal öldü!” (KTU 1.5.vi.17-23) Johannes C. de Moor, An Anthology of Religious Texts from Ugarit, s. 80. Nicolas Wyatt, "The religion of Ugarit: An Overview", Handbook of Ugaritic Studies, eds. W. G. E. Watson, N. Wyatt (Leiden: Brill, 1999), s. 578.

26 Ralph K. Hawkins, While I Was Praying: Finding Insights about God in Old Testament Prayers (Macon: Smyth\&Helwys Publishing., 2006), s. 89.

27 John Day, "Hosea in the Baal Cult", Prophecy and the Prophets in Ancient Israel, ed. J. Day (London: T\&T Clark, 2010), s. 214. 
Ugarit Metinleri Çerçevesinde Baal Tapıcılığı ve İsrailoğulları'na Etkisi ayrılmışlığı söz konusu değildir. Nitekim Yahve, İsrail'in Baal tapıcılığıyla elde ettiğini sandığı lütuf ve nimetleri hâlâ kendisi sağlamaktadır. ${ }^{28}$

Hoşea ise aynı tasvir doğrultusunda İsrail halkını bir kadına benzetmiş ve onlara şöyle seslenmiştir: "Anaları zina etti, onlara gebe kaldı, rezillik etti. 'Oynaşlarımın ardından gideceğim' dedi, 'Ekmeğimi, suyumu, yapağımı, ketenimi, zeytinyağımı, içkimi onlar veriyor.' (Hoş. 2:5). Hoşea'nın bu ifadesi Kenan'ın verimlilik ve bereket kültünün parçası olarak cinsel içerikli ritüel uygulamalarını ima etmektedir. Bu ritüelin yerine getirilmesiyle Baal'den yün, keten, zeytinyağı ve şarap gibi zirai verimliği güvence altına alınması hedeflenmiştir. Ancak Hoşea, İsrail halkının nimetlerin kaynağının Yahve'den ziyade Baal'e atfeden tutumunu eleştirmektedir: "Ama kendisine tahıl, yeni şarap, zeytinyağ verenin, Baal için harcadığ altınla gümüşü bol bol sağlayanın ben olduğumu bilmedi." (Hoş. $2: 8) .{ }^{29}$

Yahudi kutsal metinleri içindeki Mezmurlar, Baal kültü ile olan etkileşimin ipuçlarını yansıtan bir başka kaynaktır. Özellikle Mezmurlar 29. babda Kenan dininin panteonuna ait pek çok detay söz konusudur. Bu metin, Ugarit'te keşfedilen yazıtlardaki şiirsel anlatı özelliklerinin çoğunu içermektedir. Hatta modern okuyucunun Mezmurları Kenan dininin bilgileri çerçevesinde okumadıkça teolojik polemikleri anlayamayacağı vurgulanmaktadır. ${ }^{30} \mathrm{Bu}$ metinde Yahve'nin kendisini tabiat üzerindeki egemenliğini tanımlayan vurguları, Baal kültü çerçevesinde değerlendirilebilir. Sözü edilen metinde Yahve kendisini görkemli tanrı olarak gürleyerek engin sulara hükmettiğini, sesinin bir şimşek gibi çaktığını, çölleri titretip sarstığını ve sedir ağaçlarını kırdığını, sesinin geyikleri erken doğurtup ormanları çıplak bıraktığını bildirir. Nihayet tufan üstünde taht kurarak sonsuza dek kral kalacağını ve halkına güç vererek onları esenlikle kutsayacağını ifade eder. Öncelikle Ugarit yazıtlarındaki şiirsel anlatımların varlığı ve bunların tekrarlanması bu paralelliğe

28 Paul Nadim Tarazi, Prophetic Traditions (Crestwood: St Vladimir's Seminary Press, 1994), s. 100.

29 Merrill, Rooker, Grisanti, The World and the Word: An Introduction to the Old Testament, s. 68.

30 Rab göklerden gürledi. Duyurdu sesini Yüceler Yücesi. Dolu ve alevli korlarla. Savurup oklarını düşmanlarını dağıttı. Şimşek çaktırarak onları şaşkına çevirdi. (Mez. 18:13-14) 
işaret etmektedir. Örneğin Mezmurlar' daki Yahve imajı, Ugarit yazıtlarındaki Baal tanımıyla oldukça benzerlik göstermektedir. Yahve Mezmurlar'da güçlü bir fırtına bulutu olarak tasavvur edilmiş; onun şimşeğinin (1şık) ve gök gürültüsünün (sesi) ülkeleri titrettiği ifade edilmiştir. Baal'in de yağmur ve verimliliğin sahibi olduğu inancı dikkate alındığında, bu husus Mezmurlar'da Baal'in değil ama Yahve' nin yağmurların gücünün arkasında olduğu ifadesiyle tashih edilmiştir. Ayrıca Mezmurlar'da tufan üzerine taht kurup oturan Yahve ile mitolojik anlatıda deniz tanrisı Yam'1 alt ederek kendi krallık sarayını inşa eden Baal arasında polemik tarzında bir benzeştirme kurulmuştur.

Ugarit yazıtlarının keşfinden sonra Kitab-1 Mukaddes literatürünün doğrudan Kenan mitolojik anlatılarından imalar taşıdığı iddiası zaman zaman dile getirilmektedir. Hatta bu çerçevede Mezmurlar'ın Ugarit yazıtları paralelinde yeniden yazıldığı ileri sürülmektedir. Özellikle Mezmurlar 29'un Ugarit yazıtlarındaki anlatılarla oldukça yakın bir ilişkisi kurulmaktadır. ${ }^{31}$ Bazı bilim adamlarına göre Kenan bölgesindeki dini söylence ve ilahileri İsrail halkı tarafından kendi litürjilerine uyarlanmıştır. Bu bölümdeki fırtına anlatısı ile Ugaritik yazıtlar arasında ya da daha geniş anlamıla Kenan literatürü arasında yakın ilişki kurulmaktadır. Dolayısıyla bu benzerlikler çerçevesinde Baalizm'in İsrail'e etkisi ya da Baalizm'e karşı bir polemik dili olarak nitelense de bu benzerlikler araştırması devam eden yakın bir ilişkiyi ifade etmektedir. ${ }^{32}$

Ugarit mitolojik metinlerinde Baal'in El tarafından kral atanması, yağmur ve bereket tanrısı olması, Mot ile olan amansız mücadelesi, sonunda Mot tarafından öldürülmesine rağmen tekrar hayata dönmesi gibi güçlü etkisi nedeniyle Yahudi kutsal metnindeki Baal figürü, Yahve' nin polemiksel karşıtı halinde tasavvur edilmiştir. İsrailoğulları tarihinin uzunca bir süresinde İsrail'in Baal'in çekici görünen inanç ve ritüelleri tarafından cezbedildiği ifade edilmektedir (Hak. 2:11, 13:3-7, 6:25-32, 8:33, 10:6; 1 Sa 7:4, 12:10 vd). Yahve kudretli eylemleri ve vahyedilmiş şiirsel sözleriyle kendisinin Baal'den üstün olduğunu göstermiş ve ahitlerinden dönen İsrail halkının sadakatini onarmaya girişmiştir.

31 Bkz. Mitchell Dahood, Psalms I-II (New York: Anchor Bible, 1966).

32 Bkz. Schniedewind, Hunt, A Primer on Ugaritic: Language, Culture and Literature, s. 30 . 
Baal'in İsrail halkının kendine çeken verimlilik ve güncel kazanımlar üzerinde etki eden özelliği karşısında izlenen bu stratejinin bir parçası olarak Yahve, kendisinin Baal niteliklerine fazlasıyla sahip özelliklerle vahyetmiştir. Yahudi kutsal metninin pek çok pasajında Yahve'nin kendisi ve kudretli icraatleri, Baal mitolojisinde öykülenenlere uygun benzetme ve terimlerle anlatılmıştır. Yahve'nin pek çok icraatı, özellikle de hükümranlığına meydan okuyan krallar üzerindeki egemenliği, Baal'in kahramanlık ve egemenlik anlatılarına paraleldir ve bu anlatılar Baal'in değil kendisinin fırtına unsurlarına hükmettiği ve kaos ile ölüm üzerindeki otoritenin sahibi olduğunu göstermektedir.

Baal kültüne ilişkin uygulamaların İsrail toplumunu iki şekilde etkilediği öne sürülür: (i) Bu kültteki litürjik temalar, tasvirler ve ifadeler İsrailoğulları tarafından benimsenmiştir. Baal'e fiili olarak tapınmak kesinlikle yasaklanmış olmasına rağmen Yahve ile diğer panteonların tanrıları arasında doğal olarak teolojik bir örtüşme söz konusudur. Yahve ve Baal'in her ikisi de firtına tanrısı olarak (Eyu. 38; Mez. 29) tasavvur edilmiş; benzer ekolojik konum içinde ve benzer sıfatlarıyla düşünülmüştür. Her ikisi de "bulutların üzerinde" (Mez. 18:10; 1 Sa. 22:11; Mez. 77:18) birer savaşçıdır. Her ikisi de ortak düşmanlara sahiptir: Leviathan (Eyu. 3:8; 41:1; Mez. 74:14; Yşa. 27:1); Tannin (Eyu. 7:12; Mez. 74:13; Yşa. 51:9; Hez. 29:3) ve Yamm (Mez. 89:9). (ii) İsrailoğulları'nın senkretik eğilimleri genel olarak Baal kültü üzerine yoğunlaşmıştır. ${ }^{33}$ Bu geleneksel yaklaşıma karşın Yahve'nin Yahudi kutsal metninde Baal'in pek çok sıfat ve icraatını paylaştığ1 görülür. Yahve de bir fırtına tanrısıdır (Mez. 29); ölüm güçlerine karşı güçlü bir savaşçıdır (Çık. 15); yeryüzünün meyvesini verendir (Hoş. 2:14-23). Yahve yağmuru veren, ziraatı bereketlendiren, yeryüzünü huzurlu ve mutlu bir ortama çeviren, doğanın döngüsel ritmini sağlayan ve böylece bütün yaratıklar için yeryüzünü yaşanabilir hale getirendir (Tek. 1:1-2:25; Mez. 104:27-28; 145:15-16; Yşa. 55:12). ${ }^{34}$

Yahudi kutsal metninde Baal kültü çerçevesinde anlamlandırılan anlatı ve semboller daha da artırılabilir. Ancak ifade edilen kutsal metin söylemlerine dayanarak Yahve'nin İsrail halkı arasında

\footnotetext{
${ }^{33}$ Mark Anthony Phelps, "Baal", Dictionary of the Bible, ed., D. N. Freedman (Cambridge: Eerdmans, 2000), s. 134.

${ }^{34}$ Brueggemann, Reverberations of Faith: A Theological Handbook of Old Testament Themes, s. 16.
} 
yaygınlaşan Baal kültüne karşı şedit bir tepki gösterdiği ve Baal'e atfedilen güç ve kudretin, verimlilik ve bereketin esasen kendisine ait olduğunu vurguladığı görülmektedir. Dolayısıyla Yahve'nin Baal kültüne karşı gösterdiği tepkisel söylemler üzerinden Baal figürünün anlaşılması kısmen mümkün olmuştur.

\section{İsrail Halkında Baal Eğilimi}

İsrail kavminin Kenan bereket tanrısı Baal'e yönelmelerinin temel sebebinin, rab Yahve ile aralarındaki ilişki zorluğundan kaynaklandığı anlaşılmaktadır. Yahve, egemen, yargılayan, hükmeden, adaletini uygulayan, gerektiğinde acı bir şekilde cezalandıran yüce bir tanrıdır. Bu tanrı ilahi egemenlik alanın elinde bulundurmakta, İsrail halkının temel inanç değerleri üzerinde etkin olmaktadır. Aynı zamanda Yahve, İsrail halkının firavunun zulmünden kurtaran, onları denizlerden aşırıp özgürleştiren ve "bal ile süt memleketi" olan "vaadedilmiş topraklar"a ulaştıran bir tanrıdır. Dolayısıyla Yahve, İsrail halkının tarihini yeniden oluşturan ve onları bu tarih doktrini üzerinde yürüten ilahi bir egemenliği ifade etmektedir. Bu nedenle geleneksel olarak İsrail halkı arasında Baal kültünün yaygınlaşması için iki temel sebep sayılır. Bunlardan birincisi, bir yaratıcı tanrı olarak Yahve doğal sürecin dışındadır ve İsrail halkını etik değerler üzerine bina ettiği zorunluluklar çerçevesinde yönetir. Diğeri ise Yahve'nin tercih ettiği eylem alanı tabiattan ziyade tarih bağlamlıdır. ${ }^{35}$ Tarımsal bir çaba içinde olan İsrail halkı, böylesine kudretli Yahve ile nasıl bir bağ kuracağı konusunda belli ki zihinsel bir ikilem yaşamıştır.

İsrail halkının Kenan'a yerleşmeleri, onların ekonomilerinde önemli bir değişime yol açmıştır. Çünkü İsrail halkı Kenan'da zirai bir köy yaşamı ve tarımsal işleyiş̧ çerçevesinde şekillenmiş bir inanç ile karşılaştılar. Yerleşimci zirai yaşam, tarlaların ve bağların işlenmesini gerektirmektedir. Dolayısıyla İsrail halkı en azından Kenan halkı kadar zirai teknikleri öğrenmenin yanı sıra ürünlerin yetişmesini sağladığına inanılan verimlilik tanrılarına, yani baallere yönelik uygun ritüel ve müracaatlarda bulunma gereğine inandılar. Göçebelik gezici bir yaşamı ifade ederken ziraat toprağa bağlılığı gerektirir. Göçebelerin sosyal birliği kabile birliğine dayanırken tarımsal

35 Brueggemann, Reverberations of Faith: A Theological Handbook of Old Testament Themes, s. 15. 
sosyal birlik aile merkezinde ya da mesken çevresinde sağlanır. Bu nedenle yerleşik yaşama uymaya çalışan İbrani "kabilesi" nin tanrısı olan Yahve, tarım temelli bir aile ve mesken tanrısı olan Baal ile korkunç bir rekabet yaşamıştır. ${ }^{36}$ Yani Yahve'ye bağlılık ile Baal'in önünde eğilme arasındaki mücadele sadece inanç boyutlu değil aynı zamanda zirai bir mücadeleyi ifade etmekteydi. Yahve'nin Karmel dağındaki zaferi, ziraatın kutsallığını yok eden bir sonuç doğurmuştur. Böylece İsrail artık verimlilik ve bereket ritüellerine başvurmaksızın özgürce çiftçilik yapabilecekti. Sonuç olarak dini ve zirai kavga esasen ekonomik nedenlere dayanmaktaydı. ${ }^{37}$ Dolay1sıyla İsrail'in Baal kültüne dönük tapıcılığının ekonomik gerekçenin yer aldığı söylenebilir. İsrail halkı tarım işlerinden yüksek bir zenginlik ve refah edinme arayışı içindeydi. Bunun neticesinde Baal kültüne olan bağlılıklarının onlara bu imkânı sağlayacağını düşünmüş olmalılar (Bkz. Hoş. 2:5, 8). ${ }^{38}$ Bu nedenle yerleştikleri topraklarda tarım işleriyle uğraşan İsrail halkının "nane ve anason" gibi zirai ürünlerine "bir damla yağmur" için böylesine yüce ve tarihi bir ilahi kudrete yönelim, Kenan halkının Baal kültüne yönelmekten daha güç göründüğ̈̈ açıktır.

Hoşea metni çerçevesinde İsrail'in milli bir ekonominin sağladı̆̆ı huzur ve refah arayışı için bu kavmin Yahve ile Baal arasında İsrail'in sadakati üzerinde gerçekleşen bir mücadeleye sebebiyet verdikleri ifade edilmektedir. Söz konusu kadim coğrafyanın ekonomik gelişimi şüphesiz doğrudan ziraat ve tarım gelirlerine bağl1dır. Baal, fırtınayı, gök gürültüsünü ve yağmuru elinde tutarak yeryüzünün bereketliliği üzerinde egemenlik sahibi olmakla, tarım toplumu için Yahve'ye göre daha uygun görülmektedir. Bu durumda İsrail halkı kendilerine şu soruyu sormuştur: "Krallık ve İsrail halkı için hayatın ve huzurun sağlayıcısı kimdir, Yahve mi yoksa Baal mi?" Pek çoğu için bu sorunun cevabı açıktı ve bazıları Yahve'nin yanı sıra, bazılarıysa doğrudan Yahve'nin yerine Baal'e tapınmaya başladılar. Fakat Hoşea aracılığıyla konuşan Yahve, İsrail'in bir ve yegâne tanrısı olarak tanrısal durumunu kimseyle paylaşmayacağını bildirdi. Yahve bu itirazında Baal tapıcısı olan İsrail

36 Northrop Frye, Northrop Frye's Student Essays: 1932 - 1938 (Toronto: University of Toronto Press, 1997), s. 119.

37 Allen Verhey, Remembering Jesus: Christian Community, Scripture, and the Moral Life (Cambridge: Eerdmans, 2002), s. 259.

38 Wood, A Survey of Israel's History, s. 172. 
halkına karşı "sadakatsiz eş" benzeştirmesi çerçevesinde hukuk dili üzerinde inşa edilmiş olan suçlama ve davacı durumunda bir dil kullanmıştır. ${ }^{39}$

Hoşea metninin vurguları dikkate alındığında Baal kültünün İsrail'in Yahve bağlılığı üzerindeki etkisinin ne olduğu önemli bir soruyu ifade etmektedir. Bu soru için iki yaklaşım öne çıkmaktadır. Birincisi, Baal tapıcılığı ya da daha genel olarak Kenan tanrılarına tapınma Yahve'ye olan bağlllıkla birlikte yürütülmüştür; ikincisi, Baal kült sembollerine tapınanlar hatalı bir şekilde Yahve'ye tapındığını düşünmüştür. Pek çok araştırmacıya göre her iki anlayış da, Hoşea' daki anlatı dikkate alındığında, İsrail halkının tecrübe ettiği, daha çok Baalize edilmiş bir Yahve kültüdür. Baalize edilmiş Yahve kültü Yahve' nin dışında ve onun terk edilerek gerçekleştirilen bir tapıcılık değil Yahve inancının Baal kültüne dönüştürülmesidir. Hoşea metni bir bütün olarak düşünüldüğünde İsrail Baal tapıcıllğına doğru bir yönelim içinde olurken aynı zamanda Yahve'ye olan sözde bağlılık durumunu da devam ettirmişlerdir. ${ }^{40}$

\section{Saffât Sûresi'nde Baal}

İsrail tarihinin bir döneminde Baal'in Yahve'nin yanı sıra kutsanması ya da Yahve'nin nimetlerine ulaşmak için bu putun aracı tutulması veya "Baalleştirilmiş" Yahve inancı şeklinde tasavvur edilmesi durumlarının ilgili Kur'an ayeti çerçevesinde irdelenmesi de mümkündür. Kur'an, Saffât sûresi 124-126. ayetlerde Hz. İlyas'in diliyle, muhatap olduğu İsrail halkına yönelik serzeniş ifade edilmektedir. Söz konusu ayetlerde "Şüphesiz İlyas da peygamberlerden idi. Hani kavmine şöyle demişti: "Allah'a karşı gelmekten sakınmaz mısınız? Yaratıcıların en güzelini, sizin ve geçmiş atalarınızın rabbi olan Allah'ı birakarak Baal'e mi tapıyorsunuz?" denmektedir. İslam kaynaklarında bu ayet çerçevesinde Baal hakkında yapılan tanımların genellikle Ugarit mitolojik anlatılarıla ve Yahudi kutsal metin bildirimleriyle paralel bir yaklaşım içinde olduğu görülmektedir. Örneğin Taberi, Baal'i üç farklı anlamda tanımlarken bunlar yukarıdaki anlatımlarla uyumludur. Taberi'ye göre Baal,

\footnotetext{
39 Tarazi, Prophetic Traditions, s. 99.

40 Joy Philip Kakkanattu, God's Enduring Love in the Book of Hosea (Tübingen: Mohr Siebeck, 2006), s. 112.
} 
bir şeyin sahibi; kadının kocası; ve tarım için verimlilik putu anlamlarını taşır. ${ }^{41}$ İbn Abbas ise Baal putunu 30 arşın uzunluğunda ve dört yüze sahip bir put olarak tanımlamanın dışında bir bilgi vermemektedir. ${ }^{42}$ İslami kaynakların gerek işlevsel gerekse fiziki tanımlarının mitolojik Baal objesiyle paralel olduğu görülmektedir. Ancak, dikkat çekilmesi gereken husus, ilgili Kur'an ayeti de göz önüne alınarak Baal kültünün Arap kültüründeki karşılığının mahiyetidir.

İslam kaynaklarında Baal kavramının kadının "kocası" olarak anlamlandırılması hususu, Yahudi kutsal metnindeki Hoşea bölümündeki anlatıyı açıklar mahiyettedir. Nitekim İ. Derveze, "Baal" kelimesinin, Bakara sûresi 228. ayet ve Hûd sûresi 71-72. ayetler çerçevesinde "koca"dan kinaye olarak kullanıldığını ifade etmektedir. ${ }^{43}$ Söz konusu ayetlerden ilki, eşlerin boşanma sürecine ilişkindir ve "kocaları bu süre içinde barışmak isterlerse onları geri almada daha çok hak sahibi olduklarına" işaret etmektedir. İkincisi ise doğacak bir çocuk olarak Yakup kendilerine müjdelendiğinde Hz. İshak'ın eşinin "kocam da ihtiyarken doğuracak mıyım" sorusunu aktarmaktadır. Bu ayetlerde "koca" kelimesine karşılık gelen kelimler, Arapça okunuşuyla "be-a'-le" harflerinden oluşan türevlerdir. Dolayısıyla Arapça "ba'l" kelimesinin anlamının "koca" olduğu fark edilmektedir.

Arapça telaffuzuyla "ba'1" kavramının Hz. Peygamberin risaletinden çok önce Arapça'ya geçmiş olduğu ve Şam bölgesinden heykel/put olarak ya da en azından sadece adının Hicaz'a ulaştığı düşünülebilir. Dolayısıyla Cahiliye dönemi Araplara ait bir mabut olduğu ve hatta isminin kelime anlamı itibarıla "ailenin efendisi" ya da "ailenin sahibi" olması nedeniyle "koca" kelimesine mecazen tanımlandığı da ileri sürülebilir. ${ }^{44} \mathrm{Bu}$ durumda, gerek Ugarit metinlerinden Latinize edilmiş "baal" haliyle, gerek Arap dilindeki yazımı olan "ba'1" haliyle kelimenin genel olarak "koca" anlamina geldiği ortadadır. Meseleye böyle bakıldığında, Saffât sûresindeki ayette yer alan "baal/ba'l" ifadesinin Bakara ve Hûd sûrelerindeki

41 Taberi, Tefsir'ut-Taberi, c. 19 (Kahire, 2001), s. 614.

42 İbn Abbas, Tenvir'ül Mikbas min Tefsir-i İbn Abbas (Beyrut, 2004), s. 475.

43 İzzet Derveze, Kur'an'a Göre Hz. Muhammed'in Hayatı, c. 1, çev. M. Yolcu (İstanbul: Düşün, 2011), s. 356.

44 Bkz. Derveze, Kur'an'a Göre Hz. Muhammed'in Hayatı, s. 357. 
ayetlerde "koca" anlamına gelen "ba'l" kökü temelinde anlamlandırıldığında, kelimenin Ugarit yazıtlarındaki anlamına denk gelen bir sonuca ulaşılmış olmaktadır. Bu durumda Kur'an'ın, "Allah'ı b1rakıp Baal'e tapmak" ifadesiyle, Yahudi kutsal metinlerinde "koca" olarak sembolize edilen rabbin terk edilerek başka bir "koca" ya varmanın/mabuda tapınmanın sadakatsizlik olduğu anlamını sürdürdüğünü göstermektedir.

Cahiliye Arap toplumu söz konusu olduğunda, Baal putunun bu adıyla Arap putları arasında bulunmadığı hususu gündeme gelmektedir. Bu durumda, "ba'1" kelimesinin Arapça'ya yabancı bir kelime olması nedeniyle, kavrama yukarıda yüklenen anlamlar tartışmalı hale gelebilecektir. Ancak bu husus cahiliye döneminin büyük putlarından birisi olan Hübel çerçevesinde açıklığa kavuşturulabilir. Hübel putunun Hicaz bölgesine nasıl geldiği tartışmalı olmakla birlikte en yaygın kanaat, ticari seyahatler sırasında Hicaz'ın kuzeyinden getirildiğidir. Etimolojik olarak Hübel kelimesi, İbranice perspektifinden değerlendirildiğinde "Hâ-Bel" olarak da okunabilir. İbranice'de "hâ", Arapça'daki belirlilik anlamında marife takısına karşılık gelmektedir. Kelimeyi tamamlayan "Bel" kısmının ise "Baal" olarak okunması mümkündür. ${ }^{45} \mathrm{Bu}$ tez çerçevesinde cahiliye Arap putunun doğrudan Kenan kültünden değil İsrailoğulları üzerinden Araplara geçtiği düşünülebilir.

Cahiliye Arap toplumu, "el-İlah" bağlamında kâinatı yaratıp ekip çeviren bir rabbin olduğuna inanmaktaydı. Ancak bu rab o kadar yüce ve aşkın idi ki bu tanrıya ancak aracı unsurlar yani putlar sayesinde ulaşılacağına inanılmıştı. Yeryüzünden ve kullarından iyice uzaklaşıp tanrı bağlamında Deus Otiosus olarak nitelenen bu anlayışa göre rab olan tanrı kullarının gündelik işleriyle değil daha metafizik boyutlarla iştigal etmektedir. Hübel putu, cahiliye Araplarının gündelik işlerinde, örneğin rızık ve bereket gibi taleplerinin karşılanmasında aracı tutulan putlardan birisidir. İsrail halkının da Yahve'yi gündelik işlerin uzağında görmesi nedeniyle tarımsal bereket talebi içinde Baal'e yönelmeleri, cahiliye Arapları ile Baal eğilimindeki İsrailoğulları'nı aynı fonksiyona sahip pagan inanç üzerinde buluşturmuş olmaktadır.

45 Bkz. M. Mahfuz Söylemez, "Cahiliye Arap İnancında Putların Yeri”, Cahiliye Araplarımın Uluhiyet Anlayışı, ed., M. M. Söylemez (Ankara: Ankara Okulu, 2015), s. 37. 


\section{Sonuç}

İsrail halkı, Mısır'dan çıkarılıp Kenan ülkesine yerleşme sürecinde uzun ve çetin bir tarihi tecrübe yaşamışlardır. Firavunun zulmünden kurtulurken kendileri mucizevî bir şekilde denizden karşıya geçmişler, arkalarındaki firavun ve ordusu bu denizde boğulmuştur. Rab onlara çölün zor şartlarından gökten sofralar indirmiş, taştan sular çıkarmıştır. Sina dağının eteklerinde peygamber Musa'nın vahiy alışına adeta şahitlik etmişlerdir. Ancak işledikleri şirk ve nankörlük suçundan dolayı çölde yıllarca dolaştırılmışlardır. Dolayısıyla İsrailoğullar'nın bilincinde rab oldukça aşkın, yüceler yücesi, egemen ve adil bir tanrı olarak yer almıştır. Bu tanrı adeta onların tarihine zatıyla müdahil olmuş ve İsrail kavmi üzerinde yükselecek olan etnik temelli bir millet inşasında bulunmuştur. Bu nedenle Yahve, Mısır'dan Kenan diyarına yürüyen ve orada Kral Davud önderliğinde egemen bir devlet kuran İsrail halkı için gündelik meşgalelerin ötesinde yüce bir konumu ifade etmektedir.

İsrailoğulları çöl yolculuğunun göçebeliğine son verip toprağa bağlı yerleşik bir yaşam formuna geçmeleri, zirai faaliyetleri yaşamlarını idame ettirmelerinin temeli olmuştur. Ancak zirai yaşam doğal olarak yağmur ve buna bağlı olarak bereketi arzulayan bir tutumu gerektirmektedir. Tarlalarda yetiştirilen zirai ürünlerin ihtiyaç duydukları yağmur damlalarının İsrailoğulları'nın tarihsel seyrinde egemen bir önemi olan Yahve'den talep edilmesi, onun bu egemen ve tümel projesi içinde oldukça küçük ve önemsiz bir ayrıntıyı ifade etmiş olmalıdır. Zira Yahve İsrailoğullar'nın önce özgürleşmelerini ardından egemen bir millet olmalarını irade etmiş bir rabdir. Dolayısıyla gündelik yaşamın nispeten küçük ihtiyaçları olan yağmur ve bereket taleplerinin yüce rab Yahve'den beklenmesi, onun adeta şanını düşürücü bir anlamda değerlendirilmiş olmalıdır. Bu aşamada İsrailoğulları tarımsal hayatın bereket sorununu çevre kültürün Baal kültüne inanç ile çözdüklerini fark etmiştir. Dolayısıyla Yahve'nin İsrailoğulları'nın etnik kimlikleri üzerinde bir millet inşa edici projesiyle en üst makamda tutulması, buna karşın gündelik işlerin yürütülmesinde Baal kültünün aracılığına başvurulmuş olması söz konusudur.

Burada Baal inancına eğilim göstermiş olan İsrail halkının süreç içinde Yahve'nin yerine Baal'i ikame edip etmedikleri önemli bir temeli ifade etmektedir. İlk bakışta, Yahve'nin aşkın ve güncel üstü konumu korunurken gündelik yaşamın tali işlerinde Baal kültüne 
müracaat edildiği görülmektedir. Ancak peygamber İlyas'ın Karmel dağ 1 tecrübesi, İsrail halkının zaman içinde Yahve'yi unutup Baal'e yöneldiklerini, ona da kurbanlar sunduklarını, hatta Yahve ile Baal arasında hangisinin kurbanı kabul edeceğine dair bir rekabete girdikleri görülmektedir. Bu durumda Yahve'nin Baal tapıcısı haline gelen İsrail halkını "kocasını terk edip başka birisine kaçan eş" benzetmesi, İsrail halkının Yahve'ye olan sadakatsizliğini ve unutmuşluğunu ifade etmektedir.

İsrailoğulları açısından Baal kültünün etkisi çerçevesinde Kur'an'ın ilgili ayeti önem kazanmaktadır. Baal tapıcısı İsrail halkına "Allah'ı bırakarak Baal'e mi tapıyorsunuz" sorusunu yönelten ayet, Yahudi kutsal metinleri ve Ugarit yazıtlarındaki Baal tanımı çerçevesinde ele alındığında, İsrailoğulları'nın düştüğü şirk haline işaret etmektedir. İsrail halkının gündelik yaşamın maişet arayışı içinde gerçek rableri yerine Baal putuna yönelerek ondan bereket ve rızık talebinde bulunmaları, ayette dikkat çekilen "Allah'ın bırakılıp Baal'e tapınılmasını" ifade ettiği açıktır. Dolayısıyla rabbin hayatın dişında yüce ve üstün bir mercii olarak değerlendirilip dünyevi talepler için aracı unsurlara yönelmek ve onlardan taleplerde bulunmak, Yahudi kutsal metninin diliyle "kocaya sadakatsizlik yapmak" anlamında sadakatsizlik, Kur' an'a göre ise "Allah'ı bırakmak" anlamına şirk durumunu ifade etmektedir.

\section{Kaynakça}

Allen Verhey, Remembering Jesus: Christian Community, Scripture, and the Moral Life (Cambridge: Eerdmans, 2002).

An Anthology of Religious Texts from Ugarit, ed. J. C. de Moor (Leiden: Brill, 1987).

Brad E. Kelle, Hosea 2: Metaphor And Rhetoric in Historical Perspective (Atlanta: Society of Biblical Literature, 2005).

Mark Anthony Phelps, "Baal”, Dictionary of the Bible, ed., D. N. Freedman (Cambridge: Eerdmans, 2000),

E. H. Merrill, M. F. Rooker, M. A. Grisanti, The World and the Word: An Introduction to the Old Testament (Nashville: B\&H Publishing, 2003).

Erin Wolff, A Heart After God (Lake Mary: Creation House, 2013).

Frank Moore Cross, Canaanite Myth and Hebrew Epic: Essays in the History of the Religion of Israel (Cambridge: Harvard University Press, 1997).

İbn Abbas, Tenvir'ül Mikbas min Tefsir-i İbn Abbas (Beyrut, 2004).

İzzet Derveze, Kur'an'a Göre Hz. Muhammed'in Hayatı, c. 1, çev. M. Yolcu (İstanbul: Düşün, 2011). 
Ugarit Metinleri Çerçevesinde Baal Tapıcılığı ve İsrailoğulları'na Etkisi

Johannes C. de Moor, An Anthology of Religious Texts from Ugarit (Leiden: Brill, 1987).

John Day, "Hosea in the Baal Cult", Prophecy and the Prophets in Ancient Israel, ed., J. Day (London: T\&T Clark, 2010).

John Day, Yahweh and the Gods and Goddesses of Canaan (Sheffield: Sheffield Academic Press, 2002).

John Gibson, "The Mythological Text", Handbook of Ugaritic Studies, ed. W. G. E. Watson, N. Wyatt (Leiden: Brill, 2003), s. 193.

Joy Philip Kakkanattu, God's Enduring Love in the Book of Hosea (Tübingen: Mohr Siebeck, 2006).

K. L. Noll, Canaan and Israel in Antiquity: An Introduction (New York: Sheffield Academic Press, 2001).

Lamoine Devries, "Baal”, Mercer Dictionary of the Bible, ed., W. E. Mills, R. A. Bullard (Macon: Mercer University Press, 1997).

Leon James Wood, A Survey of Israel's History (Grand Rapids: Zondervan, 1986).

M. Mahfuz Söylemez, "Cahiliye Arap İnancında Putların Yeri”, Cahiliye Araplarının Uluhiyet Anlayışı, ed., M. M. Söylemez (Ankara: Ankara Okulu, 2015).

Mitchell Dahood, Psalms I-II (New York: Anchor Bible, 1966).

Nick Wyatt, Religious Texts from Ugarit (London: Sheffield Academic Press, 2002).

Nicolas Wyatt, "The religion of Ugarit: An Overview", Handbook of Ugaritic Studies, eds. W. G. E. Watson, N. Wyatt (Leiden: Brill, 1999) s. 578.

Northrop Frye, Northrop Frye's Student Essays: 1932 - 1938 (Toronto: University of Toronto Press, 1997).

Patric D. Miller, The Religion of Ancient Israel (Luisville: Westminister John Knox Press, 2000).

Paul Nadim Tarazi, Prophetic Traditions (Crestwood: St Vladimir's Seminary Press, 1994).

Ralph K. Hawkins, While I Was Praying: Finding Insights about God in Old Testament Prayers (Macon: Smyth\&Helwys Publishing., 2006).

Steve Sampson, Confronting Jezebel: Discerning and Defeating the Spirit of Control (Bloomington, Chosen Books, 2012).

Taberi, Tefsir'ut-Taberi, c. 19 (Kahire, 2001).

Trent C. Butler, Holman Old Testament Commentary - Hosea, Joel, Amos, Obadiah, Jonah, Micah (Nashville: B\&H Publishing, 2005).

V. H. Matthews, J. C. Moyer, The Old Testament: Text and Context (Grand Rapid: Baker Academic, 2012).

W. M. Schniedewind, J. H. Hunt, A Primer on Ugaritic: Language, Culture and Literature (Cambridge: Cambridge University Press, 2007). 


\section{Hakan OLGUN}

Walter Brueggemann, Reverberations of Faith: A Theological Handbook of Old Testament Themes (Louisville: John Knox Press, 2002).

Winkie Pratney, Devil Take the Youngest (Lindale: Minstry of Helps, 1985). 


\section{MILEL VE NIHAL}

inanç, kültür ve mitoloji araştırmaları dergisi

Cilt/Volume: 11 Sayı/Number: 2 Temmuz - Aralık / July - December 2014

ISSN: 1304-5482

Bu dergi uluslararası EBSCO HOST Research Databases veri indeksi ve

TÜBITAK-ULAKBİM Sosyal ve Beşeri Bilimler Veri Tabanı tarafından taranmaktadır.

\section{Sahibi / Owner}

Milel ve Nihal Eğitim, Kültür ve Düşünce Platformu Derneği adına Şinasi Gündüz

$$
\begin{aligned}
& \text { Yazı İşleri Sorumlusu / Legal Representative } \\
& \text { Yasin Aktay }
\end{aligned}
$$

Editör / Editor

Şinasi Gündüz

Editör Yrd. / Co-Editor

Cengiz Batuk

Hakan Olgun

\section{Yayın Kurulu/ Editorial Board*}

Alpaslan Açıkgenç, Ayaz Akkoyun, Yasin Aktay, Mahmut Aydın,

Cengiz Batuk, Şinasi Gündüz, İbrahim Kayan, Hakan Olgun, Necdet Subaşı,

\section{Burhanettin Tatar}

\section{Danışma Kurulu/Advisory Board*}

Baki Adam (Prof. Dr., AÜ); Mohd. Mumtaz Ali (Prof. International Islamic U. Malezya); Adnan Aslan (Prof.Dr., Süleyman Şah Ü.); Kemal Ataman (Doç.Dr., Uludağ Ü.); Mehmet Akif Aydın (Prof. Dr., Marmara Ü.); Yılmaz Can (Prof. Dr., OMÜ); Ahmet Çakır (Doç. Dr., OMÜ); Mehmet Çelik

(Prof. Dr., Celal Bayar Ü.); Waleck S. Dalpour (Prof. University of Maine at Farmington); İsmail

Engin (Dr., Berlin); Cemalettin Erdemci (Prof.Dr. YYÜ); Tahsin Görgün (Prof.Dr., 29

Mayıs Ü.) Ahmet Güç (Prof.Dr., Uludağ Ü.); Recep Gün (Doç. Dr., OMÜ); Ö. Faruk Harman

(Prof.Dr., Mar.Ü.); Erica C.D. Hunter (Dr., Cambridge U.); Mehmet Katar (Prof. Dr., A.Ü.);

Mahmut Kaya (Prof. Dr., İ.Ü.); Sadık Kılıç (Prof.Dr., Atatürk Ü.); Şevket Kotan (Y.Doç.Dr., İ.Ü.); İlhan Kutluer (Prof.Dr., Mar. Ü.); George F. McLean (Prof. Catholic Univ., Washington DC); Ahmet Yaşar Ocak (Prof. Dr., Hacettepe Ü.); Jon Oplinger (Prof. University of Maine at Farmington); Ömer Özsoy (Prof.Dr., Frankfurt U.); Roselie Helena de Souza Pereira (Mestre em

Filofia-USP; UNICAMP Brasil); Ekrem Sarıkçıŏlu (Prof.Dr., SDÜ); Hüseyin Sarıoğlu (Prof.Dr.,

İÜ); Bobby S. Sayyid (Dr. Leeds U.); Mustafa Sinanoğlu (Prof.Dr., 29 Mayıs Ü.); Mahfuz Söylemez

(Prof.Dr. IÜ); Necdet Subaşı (Y.Doç.Dr., DİB); Bülent Şenay (Prof.Dr., UÜ); İsmail Taşpınar

(Prof.Dr. Mar.Ü.); C. Sadık Yaran (Prof.Dr., OMÜ); Ali Murat Yel (Prof.Dr., Fatih Ü.); Hüseyin Yılmaz (Doç.Dr., YYÜ); Ali İhsan Yitik (Prof. Dr., DEÜ)

* Soyadına göre alfabetik sıra / In alphabetical order

\section{Kapak ve Sayfa Tasarımı / Cover \& Page Design} İnan Avc1

Baskı / Publication

Ladin Ofset - İstanbul, Haziran 2015

2.Mat. Sit. 3 NB 15 Topkapi İstanbul / İsmail Tüz 02125012418

Yönetim Yeri / Administration Place

Milel ve Nihal Eğitim, Kültür ve Düşünce Platformu Derneği

Fevzipaşa Cad. Şehit Mehmet Sarper Alus Sok. No: 5, K.: 3, Tel: (0212) 5339731 Fatih/İstanbul www.milelvenihal.org e-posta: dergi@milelvenihal.org

Milel ve Nihal yılda iki sayı olarak altı ayda bir yayımlanan uluslararası hakemli bir dergidir. Milel ve Nihal' de yayımlanan yazıların bilimsel ve hukuki sorumluluğu yazarlarına aittir. Yayım dili Türkçe ve İngilizce'dir. Yayımlanan yazıların bütün yayın hakları Milel ve Nihal'e ait olup, yayıncının izni olmadan kısmen veya tamamen basılamaz, çoğaltılamaz ve elektronik ortama taşınamaz. Yazıların yayımlanıp yayımlanmamasından yayin kurulu sorumludur. 


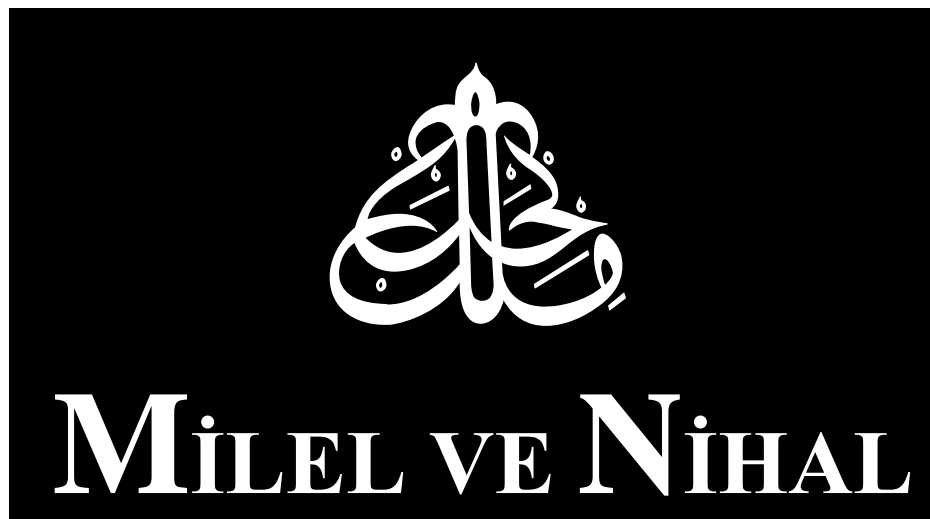

inanç, kültür ve mitoloji araştırmaları derogisi

ISSN: 1304-5482

Cilt/Volume: 11 Sayı/Number: 2

Temmuz - Aralık / J uly - December 2014 


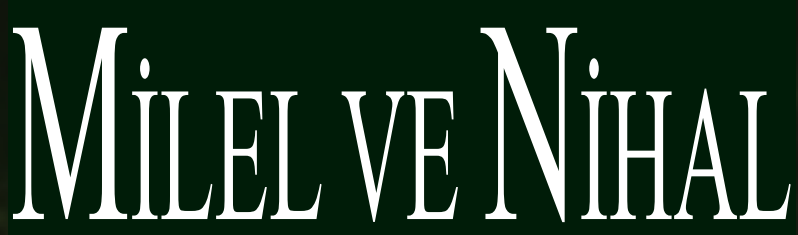

inanç, kültür ve mitoloji araştırmaları dergisi

ISSN 1304-5482

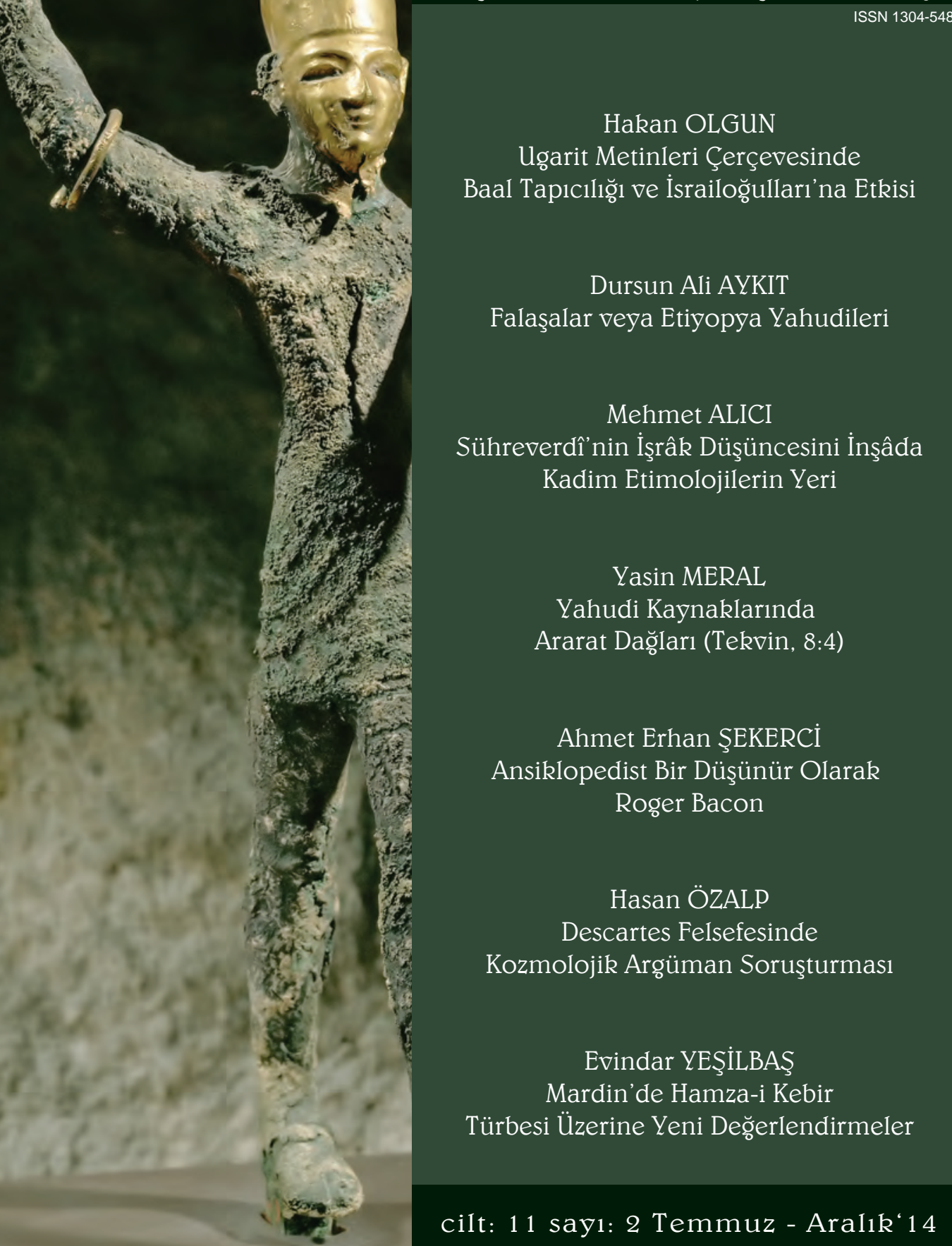

